\title{
PRISON LABOR IN THE DISTRICT OF COLUMBIA
}

\author{
By William H. Baldwin, \\ Washington, D. C.
}

Though the District of Columbia, like Bethlehem, is little among the states in point of size, it is not the least among the princes of the nation so far as its position in regard to prison labor is concerned; for by its experience it has established and confirmed a principle important not only for the salvation of families neglected by the husband and father, but also, if properly extended, of those deprived of the support to which they are entitled by the imprisonment of the father or bread-winner for any cause.

The provision resembling this in its results which had worked well for several years, in spite of some hindrances, in Toledo, Ohio, had been annulled because of unconstitutionality as special legislation some time before. It was proposed, in introducing the nonsupport law in the District in 1905 , to have the act include a provision by which the family should receive fifty cents per day for each day's hard labor performed by men committed for non-support, hard labor being an invariable accompaniment of all sentences. Various difficulties in the way of securing and carrying out this provision were brought forward, but these all disappeared as the effort for the law progressed, and it was finally enacted on March 23, 1906.

The per diem payment had been arrived at from the fact that labor such as was actually being done by such prisoners in taking care of our beautiful Rock Creek Park was worth $\$ 1.50$ per day, out of which approximately $\$ 1.00$ should be retained to pay for the cost of keeping and guarding them, and for time lost in their being taken to and from work. The experimental appropriation of $\$ 200$ for such compensation for each of the first two years, while amounting to little in itself, established the principle, and it was very gratifying to have the women appear on Monday, their "pay day," to receive the $\$ 3.00$ earned by their husbands the previous week. This payment reconciled them to having the husband punished as he deserved and kept them from begging for his release because they were absolutely deprived of the money which he might pos- 
sibly, but almost certainly would not, earn if released without the salutary effect of the imprisonment. The principle having been established, the appropriation for the fiscal year 1909 was raised to $\$ 2,400$ to provide adequately for such compensation to needy families.

Here an instance occurred which illustrates the confusion of thought and lack of knowledge in such matters. A member of the sub-committee on appropriations for the District, who came from a district in the far South in which the fifteen counties all told did not contain half the population of Washington, passed the prisoners one day in Rock Creek Park. The energy of their movements was apparently not up to his standard, and he sought to show his zeal for the protection of the interests of this great nation not only by insisting that the appropriation of $\$ 2,000$ asked for the succeeding year should be refused, but by inserting instead in the appropriation bill a clause repealing the provision in the law calling for such payments. This action at once revealed the importance of the provision, which had originally been inserted rather because of its theoretical appropriateness than because it was supposed to have so much practical value. Judge DeLacy of the juvenile court declared that the loss of the provision would be disastrous to his work, and although the congressman was shocked at the thought of providing the prisoners with board, lodging, lights and "even baths," at public expense, and allowing this compensation to the family in addition, it was explained to him that he was not called upon by the citizens of the District, who pay half the taxes, to endeavor to take the bread from the mouths of destitute women and children in order to save money for the public, and the necessary appropriation was granted. This incident cleared the air and there has been no trouble about it since.

The record of results for the six years is as follows:

\begin{tabular}{|c|c|c|c|c|}
\hline Fiscal Year ended June 30th. & $\begin{array}{l}\text { Appropriation } \\
\text { made for } \\
\text { payment of } \\
\text { earnings }\end{array}$ & $\begin{array}{c}\text { Paid for earn- } \\
\text { ings of men } \\
\text { under sentence }\end{array}$ & $\begin{array}{c}\text { Collected from } \\
\text { men under } \\
\text { sentence }\end{array}$ & Totals \\
\hline 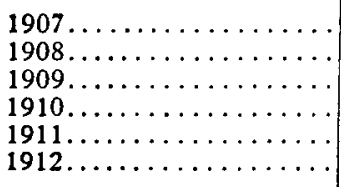 & $\begin{array}{r}\$ 200.00 \\
200.00 \\
2,400.00 \\
2,000.00 \\
3,500.00 \\
3,000.00\end{array}$ & $\begin{array}{r}\$ 200.00 \\
190.50 \\
2,340.00 \\
1,692.50 \\
3,447.50 \\
3,000.00\end{array}$ & $\begin{array}{l}\$ 6,050.59 \\
21,888.56 \\
38,319.65 \\
30,808.28 \\
38,684.97 \\
39,205.11\end{array}$ & $\begin{array}{l}\$ 6,250.59 \\
22,079.06 \\
40,659.65 \\
32,500.78 \\
42,132.47 \\
42,205.11\end{array}$ \\
\hline Totals & $\$ 11,300.00$ & $\$ 10,870.50$ & $\$ 174,957.16$ & $\$ 185,827.66$ \\
\hline
\end{tabular}


It will be noticed that the amount paid out for earnings in the workhouse is less than seven per cent of the amount collected from men under suspended sentence, but it has been perhaps the greatest factor in securing the regular payment of these sums. This payment for earnings is not a loss to the public. It is like the water used in priming a pump, which starts a steady stream that may be made to flow indefinitely.

One reason for making the men work in Rock Creek Park was that the old workhouse was overcrowded. In 1910 the government purchased 1,154 acres of land at Occoquan, about twenty miles from the city, and in June prisoners were sent down to begin the construction of buildings in the proper development of the property. By July 1, 1911, accommodations for men, and women, too, had been provided, roads had been constructed and a filtration plant, an ice plant and a sewage system established, all at a relatively small outlay, because the labor was almost all performed by prisoners. A brick-making plant with a capacity of 40,000 bricks per day had been constructed, and a stone quarry with a capacity of several hundred cubic yards of stone per day opened up; and after the completion of the buildings, prisoners were put to work in these to furnish the brick and stone needed by the District in the construction of sewers and for its other work. These buildings are kept in clean and wholesome condition and as white as whitewash can make them. A large part of the sides are glass, which can be thrown open during the warmer weather, so that during most of the year the prisoners, in effect, sleep out of doors, as they would do in a sanitarium for tuberculosis. As Commissioner Judson stated in his report: "From records kept it is apparent that those who pass through this institution come out in very much improved physical condition and hardened to work. The luxuries provided for the prisoners are inexpensive, consisting of plenty of sunshine, fresh air, work and cleanliness. These luxuries do not tempt men to break into jail, are not costly to the community, but are reforming and improving influences."

Could anything better demonstrate the healthy influence of honest work in all our prison system? It is evident that the work, while not competitive, meets a legitimate demand, and, without being specially difficult of direction, has a decided value. From a commercial standpoint the payment of $\$ 3.00$ per week to the families 
of men committed for non-support is not charity, but only a proper direction of the man's potential earning power, particularly since they now work all day long without losing the time formerly consumed in taking them from the workhouse to Rock Creek Park and back. The system ought to be extended so that the same payment will be made to those dependent upon any man committed for any other offense; and still further so that any man whose earnings are not required by persons dependent upon him may accumulate the like sum of $\$ 3.00$ per week as a fund for his support after being released, which will keep him out of temptation and carry him along until he can obtain suitable work, for which his experience in the healthy, open-air work at Occoquan has prepared him.

Provision for indeterminate instead of the present short-term definite sentences would add much to the usefulness of the workhouse, and by keeping such men longer under these favorable influences would start again towards port some of those who are already considered, or are fast becoming, the derelicts of society.

The wretched conditions in the jail, due largely to overcrowding and idleness, by which the government had long been disgraced, and of which Justice Wendell P. Stafford spoke most earnestly at the annual banquet of the University Club here six years ago, no longer exist, thanks to the attention of which that was the beginning. The jail was turned over to the District authorities on July 1, 1911, after the workhouse was established, and provision made by law for the transfer of those committed to it to the workhouse, where they are employed at useful labor as described, instead of being kept in idleness as before. The jail is used as a place for this transfer, or for the detention of those awaiting trial, and the population has been reduced from an average of more than five hundred to about two hundred, which will be further diminished by an effort on the part of the courts to provide for speedier trials.

These improvements are part of the penal plan adopted by Congress on recommendation of the jail commission, of which Justice Stafford was chairman, which also includes a reformatory, with useful labor, much on the plan of the workhouse, but intended for young men, first offenders and the more hopeful cases, who ought not to associate with those in the workhouse. A fine tract of 1,500 acres of land, bought for the purpose in 1910, had to be given up because of the opposition of those interested in Mount Vernon, 
although it was nearly five miles distant, and no other site has yet been provided; but the legislation necessary to procure one has been recommended, and it is to be hoped that this part of the plan will be carried out ere long.

The most desperate criminals from the District are sent to the United States penitentiaries at Leavenworth and Atlarta, so that a prison of that grade here is not an absolute necessity. The probation system is working well, and with provision for the indeterminate sentence, with sufficient parole officers, and the reformatory, the penal plan of the District would be on a very satisfactory basis, with the useful labor required of all prisoners in the reformatory and workhouse as a very important feature. 